\title{
At home with eating disorders
}

\author{
Elaine Painter ${ }^{1 *}$, Kirsty Greenwood ${ }^{2}$, Belinda Caldwell ${ }^{3}$, Jeremy Freeman ${ }^{4}$ \\ From 2013 ANZAED Conference: Inspiring Change: Person and Context \\ Melbourne, Australia. 23-24 August 2013
}

This presentation will discuss the outcomes and evaluations of the organisation and delivery of the 2013 "At home with eating disorders Conference"

\section{Introduction}

With the emergence of evidence based treatments, including Maudsley Family Based Therapy parents and carers play a crucial role in early detection and efficacious treatment. But they do it in the face of significant challenges - lack of information or education, difficulties in navigating the health system, difficulty in finding suitable clinicians, and suffer significant personal and financial burdens in the process.

\section{Governance}

The conference was organised by

- F.E.A.S.T

- The Butterfly Foundation

- Eating Disorder Outreach Service (EDOS)

- ANZAED

\section{Aim of the conference}

This conference aimed to provide access for parents and carers of people with an eating disorder to a range of expert knowledge and skills so they can be better prepared and empowered to take an active role in the treatment of, and recovery from, the eating disorder.

\section{Measurable outcomes}

- Online evaluations pre and post conference

- Attendance,

- Range of Speakers and Workshops

- Budget management

- Successful Sponsorships

* Correspondence: elaine_painter@health.qld.gov.au

${ }^{1}$ Royal Brisbane \& Women's Hospital EDOS, Australia

Full list of author information is available at the end of the article
Conclusions about the extent to which the conference met its aims, as well as recommendations for future carers conference planning will be made.

This abstract was presented in the Care in Inpatient and Community Settings stream of the 2013 ANZAED Conference.

\section{Authors' details}

${ }^{1}$ Royal Brisbane \& Women's Hospital EDOS, Australia. ${ }^{2}$ Butterfly Foundation, Australia. ${ }^{3}$ F.E.A.S.T, Australia. ${ }^{4}$ ANZAED, Australia.

Published: 14 November 2013

doi:10.1186/2050-2974-1-S1-019

Cite this article as: Painter et al:: At home with eating disorders. Journal of Eating Disorders 2013 1(Suppl 1):O19.
Submit your next manuscript to BioMed Central and take full advantage of:

- Convenient online submission

- Thorough peer review

- No space constraints or color figure charges

- Immediate publication on acceptance

- Inclusion in PubMed, CAS, Scopus and Google Scholar

- Research which is freely available for redistribution

Submit your manuscript at www.biomedcentral.com/submit

\section{() Biomed Central}

